\title{
Bioactivity of Crude Extract of Cashew Nut Shell (Anacardium occidentale L.) against Cabbage Head Caterpillar (Crocidolomia pavonana F.)
}

\author{
Mia Sukma Dewi, Danar Dono*, Sri Hartati \\ Department of Plant Pests and Diseases, Agriculture Faculty, Universitas Padjadjaran, Jatinangor, West Java, Indonesia, \\ 45363. \\ *Corresponding Author: danar.dono@unpad.ac.id
}

\begin{abstract}
The crude extract of Anacardium occidentale was reported to have insektisidal activity against Cricula trifenestrata (Lepidoptera). Althought, the extract has not been tested against Crocidolomia pavonana (Lepidoptera). A research was carried out to test the effect of cashew nut shell extract on larvae and fecundity of adult female of $C$. pavonana. Toxicity of the extract tested by using feeding method to the larvae. The experiment arranged in the complete randomized design (CRD), consisted of 7 treatments and 3 repetitions. The treatments were the concentration of the extract i.e. $0.8 \%, 0.6 \%, 0.4 \%, 0.2 \%$, $0.1 \%$, and $0.05 \%$. The same treatment methode was used to test the fecundity of $C$. pavonana female that developed from larval treated extract at concentrations of $0.16 \%$ (LC30), $0.30 \%$ (LC50), $0.45 \%$ (LC70), and control. The results of the experiment showed that the extract of $A$. occidentale was toxic to larvae of $C$. pavonana with $\mathrm{LC}_{50}$ values of $0.30 \%$ at six days after application. The extract of $A$. occidentale have an antifeedant effect and lengthened the development time of the larvae. The concentration range $0.16 \%-0.45 \%$ reduced the weight of pupa, lengthened emergence time of adult, slowed down the first oviposition, reduced the egg production, shortened the life span of adult female and male, shortened the periode of oviposition of adult female, and decreased the fertility.

Keywords: Crude extract of Anacardium occidentale, Crocidolomia pavonana, toxicity, fecundity
\end{abstract}

\section{ABSTRAK}

\section{Bioaktifitas Ekstrak Kasar Kulit Biji Jambu Mete (Anacardium occidentale L.) terhadap Ulat Crop Kubis (Crocidolomia pavonana $\mathbf{F}$.)}

Ekstrak kasar kulit biji Anacardium occidentale dilaporkan memiliki kemampuan dalam mengendalikan Cricula trifenestrata (Lepidoptera). Namun, ekstrak tersebut belum diketahui potensi toksisitasnya terhadap Crocidolomia pavonana (Lepidoptera). Penelitian ini dilakukan untuk menguji pengaruh ekstrak kulit kacang mete terhadap larva dan fekunditas imago betina C. Pavonana. Toksisitas ekstrak diuji dengan metode residu pada daun pakan larva. Percobaan disusun dalam rancangan acak lengkap (RAL), yang terdiri atas 7 perlakuan dan 3 ulangan. Konsentrasi ekstrak yang diuji yaitu $0,8 \%$, $0,6 \%, 0,4 \%, 0,2 \%, 0,1 \%, 0,05 \%$ serta kontrol. Metode perlakuan yang sama diterapkan untuk menguji fekunditas imago betina yang berkembang dari larva perlakuan yang bertahan hidup dengan konsentrasi ekstrak uji yaitu $0,16 \%\left(\mathrm{LC}_{30}\right), 0,30 \%$ $\left(\mathrm{LC}_{50}\right), 0,45 \%\left(\mathrm{LC}_{70}\right)$ yang diulang 6 kali. Hasil penelitian menunjukkan bahwa ekstrak $A$. occidentale bersifat toksik terhadap larva $C$. pavonana dengan nilai $\mathrm{LC}_{50}$ sebesar $0,30 \%$ pada enam hari setelah aplikasi. Ekstrak A. occidentale memiliki efek antifeedant dan penghambatan waktu perkembangan larva. Kisaran konsentrasi 0,16\% - 0,45\% mengurangi berat pupa, memperlambat waktu munculnya imago, memperlambat oviposisi pertama, mengurangi produksi telur, memperpendek umur imago betina dan jantan, memperpendek periode oviposisi imago betina, dan menurunkan kesuburan.

Kata kunci: Ekstrak kasar Anacardium occidentale, Crocidolomia pavonana, toksisitas, fekunditas

\section{PENDAHULUAN}

Hama utama yang selalu muncul dan menimbulkan kerusakan yang merugikan pada tanaman kubis adalah ulat daun (Plutella xylostella L.) dan ulat krop (Crocidolomia pavonana F.). $C$. pavonana dapat menyebabkan kerusakan tanaman hingga $100 \%$ bila tidak ada tindakan pengendalian yang tepat (Uhan, 1993). Ulat umumnya mengkonsumsi daun pada permukaan bagian bawah.

Hingga saat ini upaya yang sering dilakukan petani dalam mengendalikan hama adalah dengan cara kimiawi, yaitu dengan menggunakan pestisida sintetik. Dampak penggunaan pestisida sintetik oleh petani dapat mencemari lingkungan sekitarnya, merusak keanekaragaman hayati, dan organisme non target (Mahmood et al., 2016). Sebagai alternatif, saat ini mulai dikembangkan penggunaan bahan tumbuhan untuk dijadikan insektisida nabati. Insektisida nabati kembali mendapat perhatian menggantikan insektisida kimia sintetik karena relatif aman dan murah

Anacardium occidentale L.) (Anacardiaceae) merupakan salah satu tanaman yang memiliki potensi sebagai insektisida nabati. A. occidentale berperan sebagai hypoglycemic, antimicrobial, molluscidal, dan leishmanial (Dzamic et al., 2009). Kandungan asam anacardic yang ditemukan pada buah ini berperan kuat sebagai insektisida, bakterisida, dan merupakan inhibitor terhadap enzim kinase, histon acetyltransferase (HAT), lipoxygenase (LOX-1), xanthine oxidase, tyrosinase dan urease (Hamshekhar et al., 2011). Cangkang kacang mete (Anacardium occidentanle) mengandung Cairan Mete Gelap (CNSL) yang digunakan sebagai pestisida nabati. (Bande et al., 2018). Hasil penelitian Buxton et al. (2017) menunjukkan bahwa ekstrak jambu mete 
berpotensi sebagai insektisida dan dapat digunakan sebagai pengendalian Sitophilus oryzae.

Ekstrak A. occidentale telah diuji sebagai insektisida terhadap $C$. trifenestrata (ulat jambu mete), Sitophilus oryzae dan Tribolium castaneum. Hasil pengujian menunjukkan bahwa ekstrak tersebut mampu mematikan larva dan imago $S$. oryzae antara 22,50 - $55 \%$ dengan konsentrasi $6,25-10 \%$. Ekstrak A. occidentale dapat menghambat perkembangan larva hama tersebut menjadi pupa antara 37,50 - $60 \%$ dan pupa menjadi imago antara $12,50-25 \%$. Pengujian terhadap larva $T$. castaneum menunjukkan tingkat mortalitas antara 17,50 - 55\% dan 14 - 42,50 \% (Atmadja \& Wahyono, 2006). Sedangkan hasil pengujian terhadap $C$. trifenestrata memperlihatkan tingkat kematian larva antara 37,50 $87,50 \%$ dengan cara pengujian topikal dan peracunan pakan (Iskandar, 2002).

Penelitian tentang pengaruh ekstrak kulit biji jambu mete terhadap $C$. pavonana belum banyak dilakukan. Untuk itu, perlu dilakukan penelitian untuk mengetahui toksisitas ekstrak kulit biji $A$. occidentale terhadap larva dan pengaruhnya terhadap fekunditas imago betina C. pavonana.

\section{BAHAN DAN METODE}

\section{Persiapan Pakan Serangga Uji}

Pakan yang digunakan dalam percobaan ini adalah tanaman brokoli. Benih brokoli ditanam dalam pot berkapasitas $3 \mathrm{~kg}$ yang berisi campuran tanah dengan pupuk kandang dengan perbandingan 3:1. Selama pemeliharaan, tanaman brokoli tidak diberikan pestisida. Pemupukan NPK (15:15:15) dilakukan saat tanam dan diulang pada umur tanaman satu bulan sebanyak 1,5 g per polybag. Daun tanaman brokoli yang berumur dua bulan dapat digunakan sebagai daun perlakuan atau daun pakan serangga uji.

\section{Perbanyakan Serangga Uji C. pavonana}

Serangga uji yang digunakan dalam percobaan ini adalah larva C. pavonana instar II awal dan serangga dewasa (jantan dan betina). C. pavonana diperoleh dari Laboratorium Fisiologi dan Toksikologi Departemen Proteksi Tanaman Fakultas Pertanian Institut Pertanian Bogor.

Larva diperbanyak dalam kotak pelastik berukuran 34 x $28 \times 7 \mathrm{~cm}^{3}$ yang dialasi dengan kertas buram, kertas ini berfungsi agar kotak plastik tidak terlalu basah. Alas diganti setiap hari, dan pemberian pakan dilakukan 2 kali sehari. Pada saat larva akan berkembang menjadi pupa, bagian bawah kotak pemeliharaan diberi tanah steril untuk pembentukan kokon. Larva yang sudah berkembang menjadi pupa, selanjutnya dipindahkan ke dalam kurungan tempat pemeliharaan imago berukuran 44,5 x 44,5 x 49,5 $\mathrm{cm}^{3}$ dan diberi makan cairan madu (10\%) yang diserapkan pada segumpal kapas.

Sebagai tempat peletakkan telur, daun daun brokoli yang pangkalnya dicelupkan dalam botol kecil (diameter $3 \mathrm{~cm}$ tinggi $6 \mathrm{~cm}$ ) yang berisi air kemudian botol dimasukkan ke dalam kurungan. Telur yang diletakkan pada daun brokoli tersebut tersebut dipanen lalu ditempatkan dalam wadah plastik yang berukuran $10 \times 9 \times 4,5 \mathrm{~cm}^{3}$ dengan lubang udara pada tutupnya. Wadah kotak plastik tersebut dilapisi kertas tissue di bagian dasar kotak. Telur yang menetas kemudian berhasil berkembang menjadi larva instar II awal (6 jam setelah pergantian kutikula) digunakan sebagai larva uji.

\section{Pembuatan Ekstrak Kasar Kulit Biji $A$. occidentale}

Kulit biji buah jambu mete yang telah kering udara diblender, kemudian direndam dengan metanol dengan perbandingan $8: 1=$ kulit biji: metanol. Perendaman dilakukan selama 3 x 24 jam. Larutan tersebut disaring dengan menggunakan kertas saring. Ampas yang diperoleh direndam ulang yang dilakukan sebanyak 3 kali pengulangan untuk memaksimalkan proses ekstraksi. Larutan hasil penyaringan, kemudian diuapkan pelarutnya menggunakan rotary evaporator (IKA.WERKE HB4 Basic, tipe D-79219) pada suhu $50{ }^{\circ} \mathrm{C}$ dan tekanan $580-600 \mathrm{mmHg}$.

Ekstraksi dengan metanol kulit biji $A$. occidentale sebanyak $1,5 \mathrm{~kg}$ (kering udara), diperoleh ekstrak metanol sebanyak 542,42 g (36,16\%) ekstrak cair dan 79,72 g (5,32\%) ekstrak padat. Ekstrak yang digunakan untuk pengujian adalah ekstrak cair. Ekstrak tersebut ditempatkan ke dalam lemari es dengan suhu $\pm 4{ }^{\circ} \mathrm{C}$, dan dikeluarkan pada saat dibutuhkan.

\section{Pelaksanaan Percobaan}

Percobaan I. Uji Toksisitas Ekstrak Kasar Kulit Biji A. occidentale terhadap Mortalitas Larva $C$. pavonana

Ekstrak yang digunakan dalam uji toksisitas diperoleh dengan cara, melarutkan ekstrak kasar kulit biji A. occidentale dengan campuran metanol dan aseton sebanyak $5 \%$, lalu dicampur dengan perekat (Agristik) sebanyak $1 \%$, kemudian ditambah dengan akuades ke dalam labu ukur hingga $100 \mathrm{ml}$. Untuk kontrol, dilakukan pencampuran larutan yang sama tanpa penambahan ekstrak kasar kulit biji $A$. occidentale.

Dua potong daun brokoli berukuran $4 \times 4 \mathrm{~cm}^{2}$ dicelupkan ke dalam masing-masing larutan campuran selama 10 detik. Pencelupan dilakukan pada dua permukaan daun, yang kemudian dikeringudarakan. Larva II sebanyak 10 ekor beserta potongan daun dimasukkan ke dalam kotak plastik berukuran $\quad 10 \times 9 \times 4,5 \mathrm{~cm}^{3}$. Pemberian pakan terus dilakukan selama 48 jam, yang selanjutnya tetap diberi pakan namun tanpa perlakuan.

Pengamatan dimulai sejak hari pertama pemberian pakan sampai dengan terbentuknya larva instar IV. Peubah yang diamati ialah moralitas 
serangga uji, lama perkembangan, dan luas daun dikonsumsi larva.

Mortalitas larva dicatat sesuai dengan waktu yang telah ditentukan. Cara untuk menghitung besar mortalitas larva adalah :

\section{Mortalitas $(\%)=\Sigma C$. pavonana mati $\times 100 \%$ $\Sigma$ C. pavonana diuji}

Jika pada kontrol terdapat larva yang mati kurang dari 20\%, maka dilakukan dengan koreksi menggunakan rumus Abbott:

$$
\operatorname{Pt}(\%)=\frac{\mathrm{Po}-\mathrm{Pc}}{100-\mathrm{Pc}} \times 100 \%
$$

Keterangan:

$\mathrm{Pt}=$ Persentase mortalitas serangga uji yang telah dikoreksi

Po $=$ Persentase mortalitas serangga uji karena perlakuan ekstrak

$\mathrm{Pc}=$ Persentase mortalitas serangga uji pada kontrol

Persentase luas daun yang dikonsumsi oleh larva C. pavonana pada percobaan dihitung dengan rumus:

Daun yan dimakan larva (\%)

= Luas daun yang dimakan larva x 100\% Luas daun total

Daun yang telah dikonsumsi larva, dihitung luasnya dengan milimeter block. Hubungan konsentrasi ekstrak dengan mortalitas larva $C$. pavonana dianalisis dengan analisis probit menggunakan program SPSS 16.0. Nilai konsentrasi letal (LC) yang diperoleh $\left(\mathrm{LC}_{30}, \mathrm{LC}_{50}\right.$ dan $\left.\mathrm{LC}_{70}\right)$ digunakan dalam uji selanjutnya (Percobaan II).

Percobaan II. Pengaruh Ekstrak Kasar Kulit Biji A. occidentale terhadap Karakter Biologi Imago Betina $C$. pavonana

Konsentrasi ekstrak biji A. Occidentale yang diuji yaitu konsentrasi letal (LC) $\mathrm{LC}_{30}, \mathrm{LC}_{50}, \mathrm{LC}_{70}$ serta kontrol yang diperoleh dari hasil Percobaan I. Larva uji yang digunakan adalah larva instar II $C$. pavonana. Daun brokoli dipotong-potong dengan ukuran 4 x $4 \mathrm{~cm}^{2}$, kemudian dicelupkan ke dalam larutan ekstrak dengan konsentrasi yang telah ditentukan. Pencelupan daun dilakukan hingga sebaran larutan ekstrak merata pada kedua sisi permukaan daun. Daun yang sudah terbasahi larutan ekstrak kemudian dikeringudarakan lalu dimasukkan ke dalam kotak plastik berukuran 10 x 9 x $4,5 \mathrm{~cm}^{3}$. Larva instar II sebanyak 10 ekor dimasukkan ke dalam kotak plastik tersebut. Pemberian pakan daun berperlakuan dilakukan selama 48 jam (dua hari) dan hari selanjutnya diberi pakan daun tanpa perlakuan hingga larva yang bertahan hidup membentuk pupa kemudian imago.

Dalam pengujian ini digunakan sembilan pasang imago normal dan sehat untuk dikawinkan.
Setiap pasang serangga dimasukkan ke dalam kurungan plastik (diameter $6,5 \mathrm{~cm}$, dan tinggi $30 \mathrm{~cm}$ ) yang berbeda. Di dalam kurungan tersebut diletakkan pula daun sawi untuk peletakan telur serta pakan imago berupa larutan madu (10 \%) yang disepkan pada segumpal kapas.

Peubah yang diamati yaitu Jumlah telur yang diletakkan betina setiap harinya, Jumlah telur total yang diletakkan per betina, Jumlah telur yang menetas, dan jumlah telur yang masih tersisa dalam ovari imago betina, serta lama hidup imago jantan dan betina. Data yang diperoleh dianalisis dengan program SPSS 16.0.

\section{HASIL DAN PEMBAHASAN}

Toksisitas Ekstrak Kasar Kulit Biji A. occidentale terhadap Mortalitas Larva $C$. pavonana

Hasil pengujian toksisistas ekstrak kulit biji $A$. occidentale terhadap larva $C$. pavonana dengan metode pencelupan daun pakan dapat menyebabkan mortalitas di setiap konsentrasi uji. Konsentrasi ekstrak yang dapat menyebabkan mortalitas sebesar $90 \%$ ditunjukkan oleh konsentrasi ekstrak 0,8\%, dan yang dapat menyebabkan mortalitas larva sebesar 10 $\%$ diperoleh pada konsentrasi $0,05 \%$ pada 6 hari setelah aplikasi (hsa) (Gambar 1).

Mortalitas larva masih rendah pada setiap perlakuan di awal pengamatan, dan makin meningkat pada pengamatan berikutnya (Gambar 1). Pada 48 jam setelah aplikasi kematian larva mulai terjadi pada beberapa konsentrasi ekstrak. Larva yang masih hidup sebagian besar menunjukkan kondisi baik. Pengamatan berikutnya, yaitu pada 3 hsa, persentase mortalitas larva menunjukkan perbedaan antara kontrol dan perlakuan ekstrak, yaitu antara $0-63,3 \%$ pada selang konsentrasi 0,05-0,8\%. Beberapa larva yang belum mati tampak kurang segar dan selera makan berkurang. Larva dan pupa A. aegypti rentan terhadap 12 ppm CNSL, larva dan pupa Anopheles subpictus rentan terhadap $38 \mathrm{ppm}$ larutan Cardanol / CNSL (Mukhopadhyay et al., 2010).

Persentase mortalitas di semua perlakuan terus mengalami peningkatan pada 4 dan 5 hsa. Namun pada hari ke 6, dua konsentrasi ekstrak terendah, tidak menunjukkan lagi peningkatan kematian larva. Peningkatan konsentrasi ekstrak kulit biji $A$. occidentale hingga $0,8 \%$ sudah termasuk efektif, karena dapat menyebabkan kematian larva hingga 90 \%. Hasil penelitian Oparaeke \& Bunmi (2006) menunjukkan bahwa kulit kacang mete sangat beracun terhadap Callosobruchus subinnotatus dan mencapai $100 \%$ kematian serangga dalam 48 jam pada $7,5 \%$ dan kematian $100 \%$ dalam waktu $72 \%$ jam pada konsentrasi 2,5 dan 5,0\%. Hasil tersebut memperlihatkan bahwa cara kerja insektisida ini tidak langsung membunuh, tetapi secra perlahan menyebabkan kematian. 


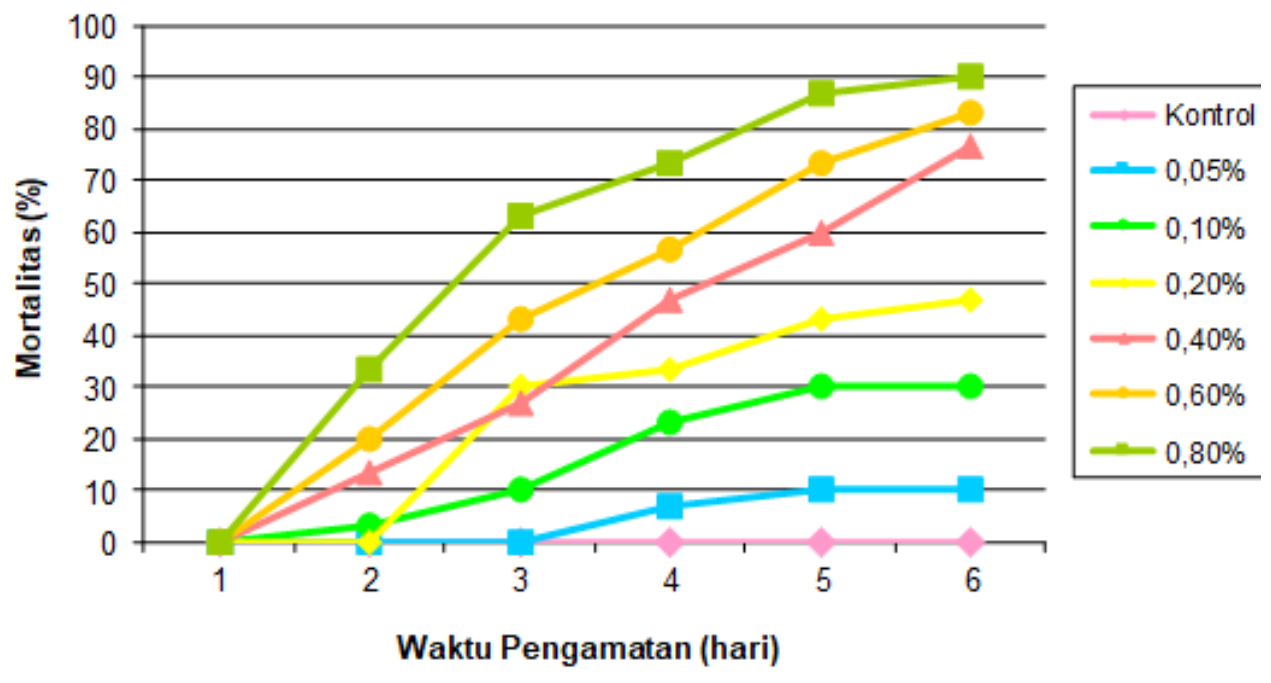

Gambar 1. Grafik Perkembangan Mortalitas Larva C. pavonana Setelah Perlakuan Ekstrak A. occidentale

Pada percobaan yang telah dilakukan, larva $C$. pavonana yang mati akibat perlakuan konsentrasi ekstrak menunjukkan beberapa gejala abnormal. Tubuh larva tidak berkembang baik atau terlihat lebih kecil dibandingkan dengan larva yang sehat, aktivitas makan menurun, dan akhirnya mati dengan warna tubuh kehitaman (Gambar 2).

Hasil analisis probit terhadap data pengamatan mortalitas pada satu sampai enam hari setelah aplikasi (hsa) dengan menggunakan progaram SPSS 16.0 menunjukkan nilai $\mathrm{LC}_{30}=0,16 \%, \mathrm{LC}_{50}=0,30 \%$ dan $\mathrm{LC}_{70}=0,45 \%$. Nilai $\mathrm{LC}_{50}$ ekstrak kulit biji $A$. occidentale mencapai angka $0,30 \%$ terhadap larva $C$. pavonana pada hari ke enam setelah aplikasi (hsa) (Tabel 1). Hal ini dikarenakan terjadi peningkatan mortalitas secara terus menerus pada hari ke dua hingga mencapai nilai tertinggi pada hari ke enam. Konsentrasi $\mathrm{LC}_{50}$ sebesar 0,30 \% menunjukkan bahwa ekstrak kulit biji $A$. occidentale sangat efektif dalam menyebabkan mortalitas terhadap larva uji $C$. pavonana.

Senyawa yang berperan menyebabkan kematian serangga uji ditunjukkan oleh hasil penelitian Buxtok et al. (2017). Hasil isolasi yang dipadukan dengan bioassay menunjukkan bahwa ada 3 senyawa yang teridentifikasi yaitu tiga mayor turunan kardanol, (Z) -3- (8- pentadecenyl) phenol (1), (8Z, 11Z) -3- (8,11-pentadecadienyl) phenol (2)dan (8Z, 11Z, 14Z) -3- (8,11,14-pentadecatrienyl) phenol (3). Dari ketiga senyawa tersebut, senyawa 3 merupakan komponen utama yang menyebabkan kematian pada $S$. oryzae dengan hasil $36,55 \mathrm{mg}$ dalam ekuivalen $1 \mathrm{~g}$ ekstrak dengan aktivitas insektisida tertinggi dengan $\mathrm{LC}_{50}$ nilai $60,36 \mathrm{mg} / \mathrm{mL}(\mathrm{SK} 95 \%=$ 64,52 - 126,41). Hidrogenasi ikatan rangkap pada rantai samping kardanol dan kardol juga mengakibatkan penurunan aktivitas larvasida terhadap Aides aegypti (Lomonaco et al., 2009).

Pengaruh ekstrak kulit biji A. occidentale terhadap perkembangan larva $C$. pavonana mulai dari instar II sampai instar IV menunjukkan bahwa eksrtak kulit biji A. occidentale berpengaruh terhadap lama stadium larva $C$. pavonana. Hasil uji Duncan pada taraf $5 \%$ menunjukkan bahwa umur larva pada kontrol berbeda nyata dengan perlakuan pada konsentrasi 0,4\%, 0,6\% dan 0,8\% (Tabel 2).

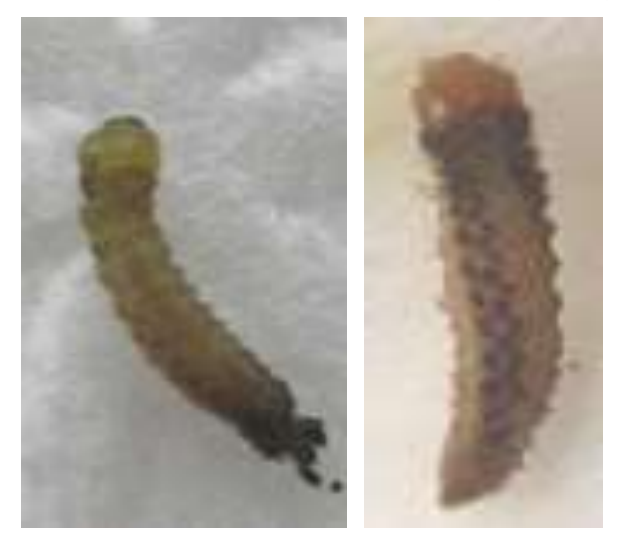

Gambar 2. Larva C. pavonana yang Menunjukkan Gejala Keracunan akibat perlakuan ekstrak kasar kuit biji A. occidentale

Perlakuan ekstrak kasar kulit biji $A$. occidentale memperlambat umur larva. Walaupun umur larva lebih lama dibandingkan dengan kontrol, tetapi larva tidak menunjukkan peningkatan aktifitas makan, bahkan cenderung berhenti untuk makan, hal ini karena waktu hidup terlama terjadi pada instar IV sampai pra pupa. Konsentrasi ekstrak tinggi menyebabkan larva lemah dan memerlukan waktu cukup lama untuk memasuki stadium berikutnya

Ekstrak kulit biji A. occidentale dapat berpengaruh terhadap aktivitas makan larva $C$. pavonana, hal ini dapat dilihat dari besarnya persentase luas daun yang dikonsumsi larva uji. Pengamatan dilakukan pada hari ke-2 setelah aplikasi. Pada percobaan yang telah dilakukan, persentase luas daun yang dikonsumsi larva uji pada semua perlakuan 
lebih sedikit jika dibandingkan dengan luas daun yang dikonsumsi larva pada kontrol. Hal ini dapat menjelaskan bahwa senyawa aktif yang terkandung dalam ekstrak kulit biji $A$. occidentale selain bersifat toksik juga berperan sebagai senyawa antifidan atau penghambat makan pada serangga uji.

Tabel 1. Hasil Analisis Probit Pengujian Ekstrak Kasar Kulit Biji A. occidentale terhadap Larva Instar IV $C$. pavonana pada 1-6 Hari Setelah Aplikasi (HSA)

\begin{tabular}{ccccccc}
\hline $\begin{array}{c}\text { Waktu } \\
\begin{array}{c}\text { Pengamatan } \\
\text { (hari) }\end{array}\end{array}$ & $\mathrm{a} \pm \mathrm{SE}$ & $\mathrm{b} \pm \mathrm{SE}$ & $\begin{array}{c}\text { Nilai } \\
\mathrm{LC}_{50}\end{array}$ & $\begin{array}{c}\text { Batas } \\
\text { Kepercayaan } \\
95 \%\end{array}$ & $\begin{array}{c}\text { Nilai } \\
\text { LC }_{95}\end{array}$ & $\begin{array}{c}\text { Batas } \\
\text { Kepercayaan 95\% }\end{array}$ \\
\hline 1 & - & - & - & - & - & - \\
2 & $-4,52 \pm 1,93$ & $0,89 \pm 0,28$ & 5,09 & $4,33-6,07$ & 6,94 & $5,99-10,45$ \\
3 & $-4,90 \pm 1,42$ & $1,25 \pm 0,52$ & 3,93 & $3,13-6,08$ & 5,24 & $4,32-12,9$ \\
4 & $-3,43 \pm 1,37$ & $1,39 \pm 0,58$ & 2,46 & $1,75-3,98$ & 3,64 & $2,88-9,96$ \\
5 & $-2,46 \pm 1,13$ & $1,42 \pm 0,61$ & 0,96 & $0,65-2,34$ & 1,75 & $1,96-8,58$ \\
6 & $-1,75 \pm 1,08$ & $0,34 \pm 0,24$ & 0,30 & $0,18-0,44$ & 0,77 & $0,58-1,23$ \\
\hline
\end{tabular}

Keterangan : $\quad \mathrm{a}=$ intersep; $\mathrm{sd}=$ standar deviasi; $\mathrm{b}=$ kemiringan garis regresi; $\mathrm{LC}=$ Lethal Concentration;

SK $=$ selang kepercayaan $95 \%$,

Tabel 2. Lama Perkembagan Larva C. pavonana Instar II-IV pada Uji Toksisitas dengan Metode Pencelupan Daun Pakan

\begin{tabular}{ccc}
\hline Konsentrasi ekstrak $(\%)$ & $\begin{array}{c}\text { Lama perkembangan larva (hari) } \\
(\mathrm{x} \pm \mathrm{SB})\end{array}$ & $\mathrm{N}$ \\
\hline 0,8 & $6,67 \pm 0,57 \mathrm{c}$ & 3 \\
0,6 & $6,33 \pm 0,57 \mathrm{c}$ & 5 \\
0,4 & $6,00 \pm 0,00 \mathrm{bc}$ & 7 \\
0,2 & $5,33 \pm 0,57 \mathrm{ab}$ & 16 \\
0,1 & $5,33 \pm 0,57 \mathrm{ab}$ & 21 \\
0,05 & $5,00 \pm 0,00 \mathrm{a}$ & 27 \\
Kontrol & $5,00 \pm 0,00 \mathrm{a}$ & 30 \\
\hline
\end{tabular}

Keterangan: Angka rata-rata yang diikuti oleh huruf yang sama pada kolom yang sama tidak berbeda nyata menurut uji Duncan pada taraf 5\%.

$$
\begin{array}{ll}
\mathrm{X} & =\text { Rata-rata lama perkembagan larva } C \text {. pavonana instar II-IV } \\
\mathrm{SB} & =\text { Simpangan Baku } \\
\mathrm{N} & =\text { Jumlah larva yang hidup }
\end{array}
$$

Aktivitas makan larva pada kontrol, konsentrasi ekstrak terendah $(0,05 \%)$ dan tertinggi $(0,8 \%)$ yaitu sebesar $58,095 \%\left(813,3 \mathrm{~mm}^{2}\right), 45,024$ $\%\left(630,3 \mathrm{~mm}^{2}\right)$ dan $11,214 \%\left(157 \mathrm{~mm}^{2}\right)$, ini berarti bahwa semakin tinggi konsentrasi ekstrak menyebabkan kondisi tubuh ulat semakin lemah dan berakibat turunnya nafsu makan (Tabel 3). Adanya efek antifidan dari senyawa aktif dalam ekstrak kulit biji A. occidentale dapat menjadi suatu faktor penyebab mortalitas pada larva uji C. pavonana.

\section{Pengaruh Ekstrak Kasar Kulit Biji A. occidentale terhadap Karakter Biologi Imago Betina $C$. pavonana}

Pengujian pengaruh ekstrak kulit biji $A$. occidentale terhadap fekunditas imago betina $C$. pavonana menunjukkan hasil yang cukup baik. Ekstrak kulit biji A. occidentale dapat menunda waktu pembentukkan telur oleh imago betina. Serangga uji pada kontrol mulai membentuk telur pada hari ke empat, sedangkan pada perlakuan $\mathrm{LC}_{30}$ dan $\mathrm{LC}_{50}$ masing-masing dimulai pada hari ke lima, dan untuk perlakuan $\mathrm{LC}_{70}$ pembentukkan telur dimulai pada hari ke enam (Gambar 3).

Fenomena ini menunjukkan bahwa ekstrak kulit biji A. occidentale pada konsentrasi 0,16-0,45 $\%$ dapat menunda waktu peletakkan telur pada imago betina $C$. pavonana selama 1-2 hari dibandingkan dengan kontrol. Penundaan pembentukkan telur dapat berhubungan dengan waktu puncak produksi telur pada imago betina $C$. pavonana. Perlakuan ekstrak kulit biji $A$. occidentale dapat memperlambat masa puncak produksi telur pada serangga uji, yaitu pada kontrol masa puncak produksi telur terjadi pada hari ke empat dengan jumlah telur 85,11 butir, sedangkan pada perlakuan $\mathrm{LC}_{30}$ pada hari ke lima dengan jumlah telur 77,33 butir, LC $_{50}$ hari ke enam dengan 71,28 butir telur, dan $\mathrm{LC}_{70}$ produksi telur terjadi pada hari ke sembilan dengan 47,5 butir telur (Gambar 3).

Ekstrak kulit biji A. occidentale dapat berpengaruh tehadap tingkat keperidian $C$. pavonana dalam pengujian ini. Hal ini terbukti berdasarkan hasil pengamatan yang dilakukan terhadap lama hidup imago betina dan jumlah telur yang dihasilkan pada setiap perlakuan dan kontrol. Tingkat keperidian 
serangga uji semakin menurun sejalan dengan semakin tingginya konsentrasi ekstrak yang diuji pada perlakuan. Pada kontrol jumlah telur yang dihasilkan imago betina sebanyak 504,89 butir dengan lama hidup 19 hari, sedangkan pada perlakuan $\mathrm{LC}_{30}, \mathrm{LC}_{50}$, dan $\mathrm{LC}_{70}$ jumlah telur yang dihasilkan serta lama hidup imago betina adalah 357,78 butir dengan lama hidup 18 hari, 299,67 butir dan lama hidup17 hari, serta 196,13 butir dengan lama hidup 17 hari (Tabel 4 dan Gambar 3). Penurunan keperidian ini disebabkan oleh kombinasi singkatnya lama hidup imago betina serta rendahnya produksi telur. Pengujian yang dilakukan Sunarjo dan Mulawati (1992) menunjukkan bahwa asam anakardat dapat berpengaruh terhadap fekunditas dengan menurunkan produksi telur wereng hijau dan wereng coklat pada dosis optimal sebesar 6 x $10^{-1} \mu \mathrm{g} /$ ekor, dengan cara kerja yang spesifik yaitu menekan produksi prostagladin synthesa pada serangga jantan.

Penggunaan ekstrak A. occidentale dalam pengujian terhadap fekunditas imago betina $C$. pavonana juga berpengaruh terhadap persentase fertilitas (telur yang menetas) serangga uji pada setiap perlakuan jika dibandingkan dengan kontrol. Pengamatan tingkat fertilitas imago betina, pada kontrol nilai persentase fertilitas sebesar 94,96\%, nilai ini lebih besar jika dibandingkan dengan perlakuann $\mathrm{LC}_{30}, \mathrm{LC}_{50}$ dan $\mathrm{LC}_{70}$ (Tabel 4)

Secara berturut-turut persentase fertilitas serangga uji mengalami penurunan sesuai dengan semakin tingginya konsentrasi ekstrak yang diuji, pada perlakuan $\mathrm{LC}_{30}$ sebesar $89,78 \%$, sedangkan pada $\mathrm{LC}_{50}$ dan $\mathrm{LC}_{70}$, masing-masing sebesar $88,87 \%$ dan $69,45 \%$. Nilai fertilitas imago betina juga dapat berkaitan dengan jumlah telur yang tersisa dalam tubuh imago betina setelah mati. Jumlah telur rata-rata yang tersisa pada kontrol sebesar 0,44 butir, sedangkan pada perlakuan $\mathrm{LC}_{30} 6,67$ butir, perlakuan $\mathrm{LC}_{50} 13,89$ butir, dan pada perlakuan $\mathrm{LC}_{70}$ sisa telur sebanyak 16,33 butir (Tabel 4). Penambahan konsentrasi pada perlakuan terhadap larva $C$. pavonana akan meningkatkan racun yang dapat mempengaruhi larva dan berdampak pada perkembangannya hingga dewasa, sehingga proses fisiologis tubuh termasuk proses reproduksi serangga uji dapat terganggu.

Berat pupa $C$. pavonana antara kontrol dan perlakuan LC30, LC50 serta LC70 menunjukkan angka yang berbeda. Berat pupa tertinggi terdapat pada larva kontrol yaitu $0,047 \mathrm{~g}$, sementara berat pupa terkecil terdapat pada perlakuan LC70 dengan 0,036 g (Tabel 4). Data tersebut menunjukkan bahwa penggunaan ekstrak kulit biji $A$. occidentale pada pengujian terhadap larva $C$. pavonana dapat mengurangi bobot pupa sejalan dengan semakin tingginya konsentrasi. Hal ini diakibatkan oleh banyak sedikitnya daun pada perlakuan yang dikonsumsi larva, sehingga berpengaruh pada pertumbuhan larva, pupa dan imago.
Ekstrak kasar kulit biji A. occidentale berpengaruh terhadap lama stadium larva, pupa, dan imago C. pavonana. Pada larva dan pupa, perlakuan ekstrak kulit biji $A$. occidentale memperlambat perkembangannya menjadi pupa dan imago. Konsentrasi ekstrak tinggi menyebabkan larva lemah dan memerlukan waktu cukup lama untuk memasuki stadium berikutnya.

Kemunculan imago pada perlakuan ekstrak lebih lama dibandingkan dengan kontrol, selain itu jumlah imago yang muncul juga lebih sedikit dibandingkan dengan kontrol. Pada kontrol persentase kemunculan imago mencapai nilai 96,67 \%, sedangkan pada perlakuan $\mathrm{LC}_{30}, \mathrm{LC}_{50}$, dan $\mathrm{LC}_{70}$ persentase kemunculan imago masing-masing sebesar 41,67\%, 45,41\%, dan $67 \%$ (Tabel 4). Sementara itu, pada imago justru sebaliknya perlakuan mempercepat lama hidupnya daripada kontrol. Hal ini berarti bahwa ekstrak kulit biji A. occidentale memperpendek umur imago (Tabel 4).

Penggunaan ekstrak pada perlakuan terhadap larva $C$. pavonana mengakibatkan senyawa racun pada daun yang diberi ekstrak masuk ke dalam tubuh larva, melalui mulut ataupun menempel pada tubuh larva. Oleh adanya senyawa racun tersebut dalam tubuh serangga, akan menurunkan pemanfaatan nutrisi untuk aktivitas pertumbuhan dan reproduksi, sehingga secara keseluruhan dapat mengganggu proses pembentukkan telur, produksi telur, masa oviposisi, dan perkembangan serangga (Chapman, 1998).

Esktrak A. Occidentale juga kurang menyebabkan efek negatif terhadap agen hayati seperti Trichoderma sp. dan Gliocladium sp. Hasil penelitian menunjukkan bahwa konsentrasi pestisida cangkang biji jambu mede $2,5 \%$ dapat meminimalkan miselium Trichoderma sp. dan Gliocladium sp. 22,73\% dan 21,04\% (Bande et al. 2018).

\section{KESIMPULAN}

Ekstrak kasar kulit biji A. occidentale bersifat racun terhadap larva $C$. pavonana dengan nilai $\mathrm{LC}_{50}$ sebesar 0,30 \% pada enam hari setelah aplikasi (hsa). Senyawa kimia yang terkandung dalam ekstrak kasar kulit biji $A$. occidentale dapat bersifat antifidan dan memperpanjang waktu perkembangan larva $C$. pavonana.

Ekstrak kasar kulit biji $A$. occidentale pada rentang konsentrasi $0,16 \%\left(\mathrm{LC}_{30}\right), 0,30 \%\left(\mathrm{LC}_{50}\right)$, dan $0,45 \%\left(\mathrm{LC}_{70}\right)$ yang diberikan pada larva $C$. pavonana melalui metode pencelupan daun pakan dapat memperlambat waktu kemunculan imago, memperlambat waktu peletakkan telur, mengurangi produksi telur, mempersingkat lama hidup imago betina dan jantan, mempersingkat masa oviposisi imago betina, serta menurunkan fertilitas. 


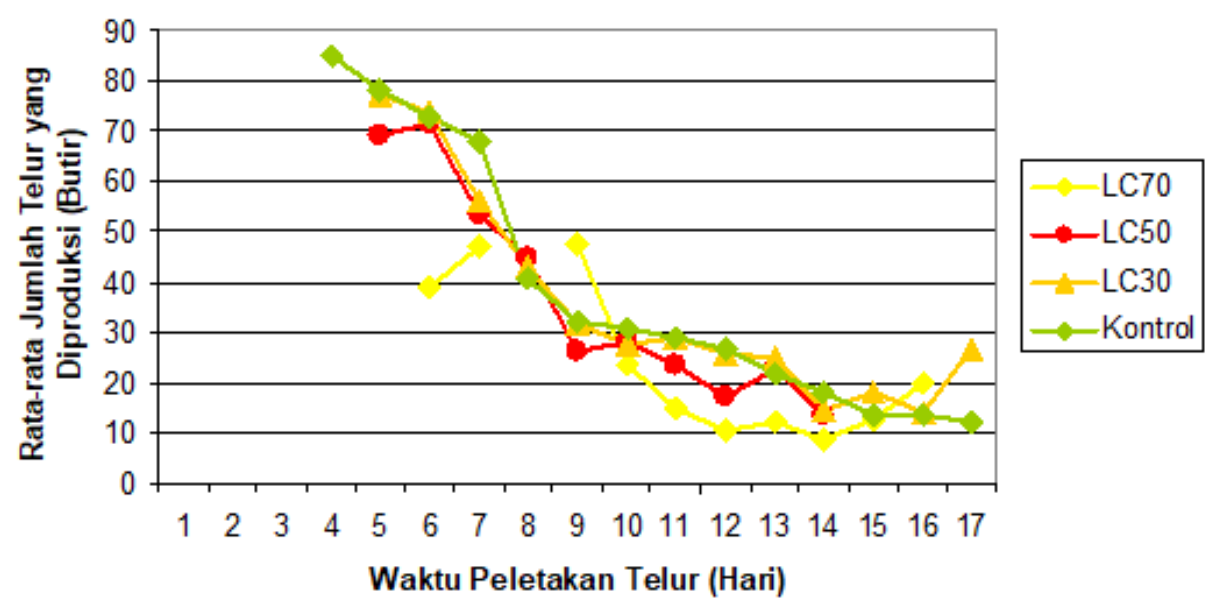

Gambar 3. Pengaruh Ekstrak Kulit Biji A. occidentale terhadap Waktu Peletakan dan Jumlah Telur pada Serangga Dewasa C. pavonana
Tabel 3. Persentase Luas Daun Sawi yang Dikonsumsi Larva C. pavonana pada Uji Toksisitas dengan Metode Pencelupan Daun Pakan pada Dua Hari Setelah Aplikasi.(HSA)

\begin{tabular}{cc}
\hline Konsentrasi ekstrak (\%) & $\begin{array}{c}\text { Luas daun yang dikonsumsi larva (\%) } \\
(\mathrm{x} \pm \mathrm{SB})\end{array}$ \\
\hline 0,8 & $11,21 \pm 0,39 \mathrm{a}$ \\
0,6 & $15,07 \pm 2,78 \mathrm{~b}$ \\
0,4 & $19,48 \pm 0,82 \mathrm{ab}$ \\
0,2 & $16,83 \pm 4,48 \mathrm{~b}$ \\
0,1 & $36,96 \pm 2,08 \mathrm{c}$ \\
0,05 & $46,32 \pm 3,62 \mathrm{~d}$ \\
Kontrol & $58,09 \pm 3,25 \mathrm{e}$
\end{tabular}

Keterangan: Angka rata-rata yang diikuti oleh huruf yang sama pada kolom yang sama tidak berbeda nyata menurut uji Duncan pada taraf 5\%.

$\mathrm{x} \quad=$ rata-rata luas daun yang dikonsumsi larva (\%)

SB $\quad=$ Simpangan Baku

Tabel 4. Pengaruh Ekstrak Kulit Biji A. occidentale terhadap Fekunditas dan Karakter Biologi imago C. pavonana

\begin{tabular}{|c|c|c|c|c|c|c|c|c|c|c|c|c|}
\hline \multirow[t]{2}{*}{$\begin{array}{c}\text { Perlakua } \\
n\end{array}$} & \multirow[t]{2}{*}{$\begin{array}{c}\sum \text { Telur/ } \\
\text { betina }\end{array}$} & \multirow{2}{*}{$\begin{array}{l}\Sigma \text { Telur } \\
\text { yang } \\
\text { menetas }\end{array}$} & \multirow{2}{*}{$\begin{array}{c}\Sigma \text { Telur/ } \\
\text { betina } \\
\text { /hari }\end{array}$} & \multirow{2}{*}{$\begin{array}{c}\Sigma \\
\text { Telur/betina } \\
/ \text { masa } \\
\text { oviposisi } \\
\end{array}$} & \multirow[t]{2}{*}{$\begin{array}{c}\text { Fertilita } \\
\text { s }(\%)\end{array}$} & \multirow{2}{*}{$\begin{array}{l}\sum \text { Telur } \\
\text { yang } \\
\text { tersisa }\end{array}$} & \multirow{2}{*}{$\begin{array}{c}\text { Masa } \\
\text { oviposisi } \\
\text { (hari) }\end{array}$} & \multicolumn{2}{|c|}{$\begin{array}{l}\text { Lama hidup } \\
\text { imago (hari) }\end{array}$} & \multirow{2}{*}{$\begin{array}{c}\text { Waktu } \\
\text { perkembangan instar } \\
\text { IV-imago (hari) }\end{array}$} & \multirow{2}{*}{$\begin{array}{c}\text { Kemunculan } \\
\text { imago } \\
(\%)\end{array}$} & \multirow{2}{*}{$\begin{array}{l}\text { Berat } \\
\text { pupa } \\
(\mathrm{g})\end{array}$} \\
\hline & & & & & & & & Jantan & Betina & & & \\
\hline $\mathrm{LC}_{70}$ & $196,13 \mathrm{a}$ & 136,22 & 11,54 & 24,51 & 69,45 & $16,33 \mathrm{c}$ & 8 & $18,0 \mathrm{a}$ & $17,1 \mathrm{a}$ & 14,5 & 41,67 & $0,036 \mathrm{a}$ \\
\hline $\mathrm{LC}_{50}$ & $299,67 \mathrm{~b}$ & 266,3 & 16,65 & 33,30 & 88,87 & $13,89 \mathrm{c}$ & 9 & $18,9 \mathrm{ab}$ & $17,6 \mathrm{a}$ & 13,06 & 45 & $0,038 \mathrm{ab}$ \\
\hline $\mathrm{LC}_{30}$ & $357,78 \mathrm{~b}$ & 321,22 & 19,88 & 29,82 & 89,78 & $6,67 b$ & 12 & $19,9 \mathrm{bc}$ & $18,2 \mathrm{a}$ & 12,33 & 61,67 & $0,041 \mathrm{~b}$ \\
\hline Kontrol & $504,89 \mathrm{c}$ & 479,44 & 26,57 & 36,06 & 94,96 & $0,44 \mathrm{a}$ & 14 & $20,4 \mathrm{c}$ & $19,3 \mathrm{~b}$ & 11,391 & 98,33 & $0,047 \mathrm{c}$ \\
\hline
\end{tabular}

Keterangan: Angka rata-rata pada perlakuan yang diikuti oleh huruf yang sama pada kolom yang sama tidak berbeda nyata menurut Uji Jarak Berganda Duncan pada taraf nyata $5 \%$

Pengamatan dilakukan pada 6 HSA. 


\section{DAFTAR PUSTAKA}

Atmaja W.R. dan Wahyono T.E., 2006. Pengaruh Chahew Nut Shell Liquid (CNSL) terhadap Mortalitas Helopeltis antonii Sign. Pada Bibit Jambu Mete. Balai Penelitian Tanaman Obat dan Aromatik. Bul. Littro. Vol. XVII No. 2.

Bande, LOS., M. Gusnawaty, HS. Nuriadi L. Trisulpa\& Rahmania. Botanical pesticides effect from shells of bean's cashew nut on biological agents of trichoderma sp. and gliocladium sp. International Conference on Agriculture, Environment, and Food Security. IOP Conf. Series: Earth and Environmental Science $\quad 122$. doi $: 10.1088 / 1755$ 1315/122/1/012047

Buxton, T. S Takahashi, I Niwata, EO Owusu, S Kim. 2017. Isolation and characterization of the insecticidal compounds in Anacardium Occidentale (cashew nut) shell liquid against the rice weevil, Sitophilus oryzae L. (Coleoptera: Curculionidae). Journal of entomology and zoology studies. 5(2):12411246.

Chapman, R. F. 1998. The Insects Structure and Function (4th Edition). Cambridge University Press, 10 Stamford Road, Oakleigh, Melbourne 3166, Australia. 770 pp.

Dzamic, A., A Gbolade, M, Ristic, PD Marin. 2009. Essential oil composition of Anaardium occidentale from Nigeria. Chemistry of natural compound, 45(3): 441-442.

Iskandar, M. 2002. Prospek CNSL (Cashew Nut Shell Liquid) Sebagai Bahan Baku Industri Insektisida Nabati. Hasil-hasil Penelitian
Tanaman Rempah dan Obat Mendukung Otonomi Daerah. Vol XIV No. 2. 2002. Puslitbangbun. Hal. 35 - 42.

Lomonaco D, Santiago GMP, Feffeira YS, Arriaga AMC, Mazzetto SE, Malle G et al. Study of technical CNSL and its main components as new green larvicides. Green Chemistry. 2009; 11:31-33.

Mahmood, I., SR Imadi , K Shazadi , A Gul, and KR Hakeem. 2016. Effect of pesticide on environment. Researchgate, hal 254-269. DOI: 10.1007/978-3-319-27455-3_13

Mukhopadhyay A.K., A.K. Hati, W. Tamizharasu, \& P.S Babu. 2010. Larvicidal properties of cashew nut shell liquid (Anacardium occidentale L) on immature stages of two mosquito species. J Vector Borne Dis 47: 257260.

Oparaeke, AM \& OJ. Bunmi, 2006. Insecticidal potential of cashew (Anacardium occidentale L.) for control of the beetle, Callosobruchus subinnotatus (Pic.) (Bruchidae) on bambarragroundnut (Voandzeia subterranea L.) Verde. Archives of Phytopathology and Plant Protection. 39(4): $247-251$

Sunarjo, P. I., \& Mulawati. 1992. Pengamatan Berbagai Efek Asam Anakardat Terhadap Wereng Padi. Kumpulah Makalah V, Padi. Kongres Entomologi IV, Yogyakarta, 28- 30 Januari 1992. Perhimpunan Entomologi Indonesia, hal. 274-284.

Uhan, T.S. 1993. Kehilangan hasil panen kubis karena ulat krop kubis (Crocidolomia binotalis Zeller) dan cara pengendaliannya. Holtikultura 3: 2226. 